\title{
ISSUES OF INCLUSION AND SPECIAL EDUCATION IN THE CREATIVE HERITAGE OF SOFIA RUSOVA
}

\author{
OKSANA DZHUS
}

\begin{abstract}
The article analyzes the issues of inclusion and special education in the creative heritage of Sofia Rusova - teacher, citizen, politician, state maker, who considered them in the context of world scientific achievements of the interwar period of the XX century. Inclusion, as a process of increasing the participation of all citizens in society, including those with physical or mental disabilities, involves the development and implementation of specific solutions that will allow each person to participate equally in academic and public life. The evolution of the idea of inclusion and the birth of special education S. Rusova closely linked with the understanding and interpretation of the leading principles of pedagogy, general and social psychology, sociology, philosophy of education, historical and pedagogical searches of the late XIX - early XX century.

Perhaps the most important source of new pedagogical ideas of S. Rusova, embodied in the writings of the interwar period ("New School of Social Education", "Education and Sociology of Durkheim", "Social Education: Its Importance in Public Life", "Public Issues of Education" became acquainted with the latest trends in Western European pedagogy, which allowed her to keep up with the times, psychologize pedagogy. Extensive education, fluency in the leading European languages (first and foremost, French) made it possible for S. Rusova to access the original literature - works by J. Dewey, E. Claapared, G. Kerschensteiner, V. Lai, E. Meiman, and G. Spencer with the most prominent pedagogical figures of the 1920s and 1930s, including O. Decroly and M. Montessori, and studying the experience of their practical work. Guided by the statement that " development of the child is influenced by three main factors: education, heritage, and environment", based on the experiments of foreign (German, Belgian, Czech) researches, the scientist revealed the specifics of social and educational impact of the environment, preparing the groundwork inclusion as a set of conditions, methods and means of their implementation for joint learning, education and development of the educational recipients, taking into account their needs and opportunities. At the same time, I emphasize the shaft that no child "is passively influenced by the environment: it takes from it what its individuality seeks." The issue of special education, in particular, the psychological and pedagogical principles of working with children with intellectual disabilities, is most fully revealed in S. Rusova's work, "Something about defective children in school". It clearly traces the idea that children of all walks of life are necessarily subject to process education and training. According to S. Rusova, children with deviant behavior (in particular, "child offenders"), for whom the conditions for education as a factor of their re-education should be created, and for the needs of such schools, should not be left out of the educational influence in order to organize teacher training "with a deep psychological understanding of their sick students, with a heart warmed with love for them, and with a certain understanding of their social and pedagogical task: to return these children to citizenship ...". Summarizing the above, it can be argued that the issues of inclusion, studying, education of children and young people with special educational needs, as represented by the property of Sofia Rusova are a significant contribution to
\end{abstract}


Ukrainian and world pedagogical thought, an important factor in the revival of national educational systems in the teaching experiences of the past.

Keywords: inclusion, special education, socialization, personality, child, vocational (professional) training, creative heritage, Sofia Rusova.

\section{INTRODUCTION}

Inclusion, as a process of increasing participation of all the citizens in society, including those with physical or mental disabilities, involves development and implementation of specific solutions that will allow each person to participate equally in academic and public life.

It should be noted that the concept of "inclusive education" in modern interpretation is a system of educational services based on the principle of ensuring the basic right of persons to education and the right to obtain it at the place of residence, which provides for the education of a child with special educational needs in the setting of a general educational establishment [1]. . It is a process in which an establishment tries to respond to the needs of all participants in the educational process by making necessary changes to the curriculum and resources to ensure equal opportunities for all persons, regardless of their psychophysical status. The Law of Ukraine "On Education" treats inclusion as "the set of conditions, methods and means of their realization for joint learning, education and development of educational recipients with regard to their needs and opportunities" [2]. The term "people with special educational needs" is most often referring to children with some disabilities. Although the law clearly states that it is "a person who needs additional permanent or temporary support in the educational process to secure his or her right to education." That means that the focus shifts: from the violation itself to the support. Accordingly, "inclusive education" is "a system of state-guaranteed educational services based on the principles of non-discrimination, respect for human diversity, effective involvement and inclusion of all its participants in the educational process" [2].

At the same time, this interpretation of the concepts is conditioned by the long development and evolution of human civilization, which attests to a clear pattern: society and education determine one another.

\section{ANALYSIS AND DisCUSSION}

Sophia Rusova - the representative of the second wave of Ukrainian emigration - a teacher, citizen, politician, statesman considered the issue of inclusion and special education in the context of world scientific achievements of the interwar period of the XX century. It is closely connected with understanding and interpretation of the leading principles of pedagogy, general and social psychology, sociology, philosophy of education, historical and pedagogical searches of the late XIX and the beginning of XX centuries and special pedagogy (special education, defectology, collector pedagogy).

Perhaps the most important source of new pedagogical ideas of S. Rusova, embodied in the writings of the interwar period, became acquaintance with the latest trends in Western European pedagogy, which allowed her to go "on an equal footing with all that is now the best what appeared on the West" on [19, p. 107]. Extensive education, fluency in the leading European languages (first and foremost, French) made it possible for S. Rusova to access the original literature - works by J. Dewey, E. Klapared, G. Kerschensteiner, V. Lai, E. Meiman, and G. Spencer with the most prominent pedagogical figures of the 1920s and 1930s, including O. Decroly and M. Montessori, and studying the experience of their practical work. Using the opinions of her foreign colleagues, S. Rusova, on the one hand, "kept the Ukrainian pedagogical world up to date on what was new and better in other countries in the field of education and upbringing", on the other - it aroused "native pedagogical thought for life, movement and progress "[19, p. 107]. That is, the purpose of her appeal to foreign pedagogical experience was to build the Ukrainian national pedagogy and school on the progressive pedagogical heritage of the world. 
Taking into account the latest provisions of the creative achievements of foreign scientists, for example, the "Program on the theory of education and training", prepared by Sofia Rusova in 1924 1925 for students of M. Drahomanov Ukrainian Higher Pedagogical Institute in Prague. The program envisaged the study of the provisions of M. Montessori's pedagogical system ("Education of the child's meanings, their role for intellectual development"), O. Decrolli's methods, "Dalton plan", the theory of labor school and civic education of G. Kerschensteiner [21, p. 10]. The opinions of foreign educators, psychologists, sociologists of the interwar period, designed by S. Rusova and adapted to the needs of the Ukrainian national school, to the peculiarities of the mentality of the Ukrainian child, were reflected in the works "Global Method in the National Schools of Czechoslovakia", "Once and Now", "Once and Now" education in public schools in Belgium", "O. Decrolli" ," Social education: Its significance in public life "," The state of modern education in the fringe corners of the world", "Modern trends in new pedagogy "and others. [20].

Opportunities for Sofia Rusova's enrichment of the world pedagogical experience were opened by participation in international educational congresses (meetings), which resulted in correspondence, articles "Two international congresses", "To Rome for two congresses", "Congress of the World Union of Educational Societies", "Congress of Educational Societies", "Idealist-educator Adolf Ferrier" [20].

While actively working on the issues of preschool education, in the last decades of her life, Sophia Rusova has been gradually focusing on the universal and national aspects of education in general. She was most interested in the social aspects of education and its latest trends. According to the teacher, education as the most important social function is able to "transform within certain limits" people's attitude, become one of the factors of his national self-determination [1, p. 7]. It should cover not only pre-school and school-age children, but also all young people, all adults, and be provided by all social institutions. This thought is a priority in many of the pedagogical works of S. Rusova in the 1920s1930s.

S. Rusova focused on the theoretical substantiation of the need for universal education and its role in the moral and social formation of the young generation, preparing it for conscious work "for their native land, for the liberation of their native people from the chains of darkness and enslavement, for improvement of their social and political conditions life".

An important feature of the works of Sofia Rusova in the war period is the priority in them of new, foreign pedagogical ideas, caused by the expansion of international educational ties of the scientist. From the works of this period she emerges as a deep connoisseur of the leading positions of the creative heritage of Western European scholars of the early XX century. Sharing many of their ideas regarding the national character of the school, the socialization and individualization of teaching and upbringing, the use of experimental research in working with children, she opposed the blind copying of other pedagogical systems, the thoughtless transfer of foreign educational and teaching methods to the Ukrainian background. Thus, analyzing the systems of primary education and training of Maria Montessori and Ovid Decroly, who in the 1920s-1930s pp. XX century were dominant in the countries of Western Europe, S. Rusova concluded that the methods of both educators should take what is most relevant to the temperament of the Ukrainian child and promote its intellectual development; in her opinion, it is "highly desirable" for these systems to be "nationalized ... and to give our very capable, vulnerable children the best education and interesting method and material" for working with them [10, p. 21].

Sophia Rusova was interested in social aspects of education and training, efforts of foreign scientists of the late XIX - the first decades of the XX century on development of social pedagogy as a science. This is confirmed by her individual works ("New School of Social Education"), articles ("Durkheim's Education and Sociology", "Social Education: Its Importance in Public Life", "Public Education Issues"), reviews of foreign publications ("I. Guyau Education et Heredite. Etude Sociologiguc", "Souriau. Notions de Sociologie, Appliquei a la Morale et a L'Education. Deuxieme annee des Scoles Normales"). In accordance with the pedagogical thought of our time in the inheritance of S. Rusova's emigration period, we see the desire to "psychologize" pedagogy. In particular, in the scientific exploration of "Modern trends in new pedagogy", she stated that "... pedagogy ... should use 
the scientific guidance of psychology, sociology and social psychology", and education and training "to rely on deep psychological research, as an individual student and the whole circle, the collective of children, as well as their environment" [15, p. 2].

Considering pedagogy as a theory of education of a comprehensively developed personality, Sofia Rusova paid considerable attention to the development of scientific foundations of pedagogical activity. Even before the pre-emigration period, she turned to the search for the answer to two questions: "1) what is the child for whom we have to create the appropriate atmosphere for her and 2) ... how to treat her so that the education has the best consequences [6, p. 307]. A thorough understanding of these global problems has led the scientist to understand that in order to solve the first question, pedagogy "must use the scientific guidance of psychology, sociology and social psychology in its theoretical study and in practical implementation" [15, p. 2]. The pedagogue analyzed the psychological basis of education of a person "adapted to the new needs of life" in separate sections of the fundamental works of the emigration period ("New School of Social Education", "New Methods of Preschool Education", "Contemporary Currents in New Pedagogy", "Theory and Pre-school" upbringing ") and in a number of research and articles. In them, she argues that psychology "looks deeply into the soul of the individual and struggles to understand his whole conscious and unconscious nature" [13, p. 4]. Hence, her firm conviction "for the upbringing of the child, as well as for its teaching, it is absolutely necessary to know the child, to understand its spiritual inclinations, its temperament, the physical composition of the organism", since "the psychological experiences of recent years have convinced all educators that the child is completely separate physical and spiritual organism" [16, p. 3]. Among the ways to "understand the child", the methods of experimental research of her inner world, S. Rusova identified and comprehensively characterized observations, diaries, questionnaires; teacher's memories of his own childhood; representation of "oneself in the position of the child"; collecting "products of children's creativity", especially drawings, etc. [8, p. 10]. From the experience of psychology, she derives the most important for all times and epochs the law of love for the child: "the child's soul needs affection, sympathy, love and not general, but personal; every child needs someone to love her the most; it cannot develop normally without maternal love and affection ..." [13, p. 8]. According to Sofia Rusova, her current psychology has "deepened" the psychological development of young children in detail. At the same time, she failed to give "almost no specific experiences ... about ... the young man's state of mind, nor instructions on his best upbringing" [8, p. 2].

Considering that the harmonious education of a person requires understanding not only the psychology of the individual, but also "that social psychology, which clarifies the relationship of the individual to the collective and the collective to the individual", Sofia Rusova emphasized the importance of social psychology for pedagogical activity [9, p. 8-9]. In the work "The value of social psychology for education" the thinker revealed the essence of the young, but one that "has very significant scientific experience", science - social psychology, as it was understood by American scientists F. Olport, C. Ellwood, J. Bernard et al. On this basis, it was concluded that social psychology is a part of the psychology of the "individual", which examines his behavior "in the sector of ... social environment", that is, gives "understanding of the relationship" of the person with the social environment, without which education is impossible [9, p. 11].

In search of an answer to the question that has a greater impact on the development of civilization the mind or emotions, and what stimulus the social environment responds to, S. Rusova tends to think that the progress of civilization relies more on emotions, sympathy than on the mind. In the process of "continuous development of the individual", the primary role belongs to the language, the knowledge of which enables to understand the behavior of other people, serves "by imitation", "adaptation" to the environment that promotes the development of the individual $[9$, p. 86]. The scientist agrees with the findings of her current psychologists that art is a kind of bridge between "imitation of people real" and symbolic images of literature and abstract social values (courage, nobility, heroism). A great role in satisfying the human race to progress, to the new ideals assigns to the persons of "original thought and strong willpower", especially in times of social change, radical reforms. In her opinion, all "high labor of civilization is a result of the work of inspired pioneers", "brilliant figures", who were made by 
nature, environment, social center [9, p. 87-88]. In the analyzed article, Sophia Rusova examines the psychological motives that encourage "the race to unite, to find one common purpose for fulfillment." The opinion of a number of foreign psychologists that they are selfish desire of the person to ensure their own interests or "desire to protect the younger members of the family", the thinker considered such that "do not have a certain scientific field" [9, p. 128].

Following German scientists M. Mayer, E. Maiman, she argued that "human groups" are formed on the basis of the cooperation of their members. S. Rusova analyzed in detail the problem of interaction and mutual influence of the individual and the group (collective) and the "unorganized crowd". On this basis, it was concluded about the social value of each individual, who "adds, though small, but his own part of the influence to the whole environment in which he lives, works" [9, p. 128-131].

With regard to the relationship between pedagogy and sociology, S. Rusova noted: sociology "is most interested in the position of a person in the community, in social relations, in duties" [13, p. 4]. Agreeing with the views on this problem scientists and practitioners of the late XIX - early XX centuries (E. Durkheim, A. Ferriere) noted that sociology, supported by biology and psychology, gives "certain directions for education", along with these sciences is the key to understanding life [12, p. 253]. Not being able to give "the very tools for pedagogical practice" to our hands, it "gives us a whole range of thoughts that should become the soul of pedagogical practice, guide it and give the whole education some meaning without which all pedagogical activity would not have the desired consequences" [4, p. 141]. Answering the question of how to provide the scientific foundations for the effectiveness of education, Sofia Rusova linked not only theoretical and methodological provisions of pedagogy and psychology, but also a philosophy that alone "can only illuminate a secret question - what should our pupil lead to, where to find for him the surest path to the ultimate world truth" [5, p. 307]. That is, the scientist's understanding of global pedagogical problems led her to consider the issues of philosophy of education. According to the contemporary researchers of the creative heritage of S. Rusova, in this field "she was a pioneer", since she was the first to translate from English into Ukrainian and put into practice the basic ideas of the work of the American philosopher and teacher G. Horn "The Philosophy of Education" ("Philosophy of Education"), outlining them in the extensive article "Some of the Philosophy of Education" as early as 1917. Sharing the scientist's thoughts, she wrote: only "a philosophical understanding of life will give a clear direction to our activity and to clarify the importance of education for the universal human progress ..." [5, p. 307]. At the same time, the thinker believed that her current pedagogy had not yet put forward "any broad philosophical thought that would guide education, would lay the ground for all practical methods and means ..." [5, p. 307]. However, it sufficiently traces the "social direction" represented by scientific researches of J. Dewey, G. Kerschensteiner, M. Montessori, P. Natorp. Therefore, in determining the essence of education, S. Rusova proceeded from the understanding of him as "one of the strongest factors in the social life of every people" [4, p. 142].

According to her, education "a nation of its youth is connected with political and social ideas, its family and social customs and world outlook" [7, p. 7]. Its purpose is closely linked to the "determination of the higher values of life", to the highest humane ideal, "ruling at that time in citizenship" [7, p. 162]. The educated person, as she asserted, is "able-bodied, socially conscious, useful in every society, in every citizenship, with exalted love for his native land and with respect for other peoples" [15, p. 2].

As it can be seen from the above, S. Rusova considered pedagogy a social science. She was one of the educators who spread the ideas of "one of the main" (in her words) representatives of the "sociological direction of education" - German philosopher and teacher, creator of social pedagogy as a separate branch of P. Natorp's knowledge [15, p. 129]. "Man becomes a man only in unity with citizenship" - this statement by P. Natorp is the basis of S. Rusova's social and pedagogical views. Among the main social and pedagogical ideas that can be traced in her writings are: the influence of living conditions (social environment) on education; dependence of the purpose and nature of education and learning on social relations and vice versa - their impact on social life, the interdependence of society and the individual. The scientist's publications answer the question of what 
should be the ideal of a socially protected child, what should be the social and educational responsibilities of the state, etc. Back in 1918 she wrote: "The most precious treasure of every nation is its children, its youth, and citizenship is made more consciously, then it is given more attention to the upbringing of children, to providing them with the best living conditions" [3, p. 34]. At the same time, it should be noted that social pedagogy as a science in the early XX century was only at the stage of its formation (the first work "Social Pedagogy" by P. Natorp was published in 1899). Therefore, S. Rusova, analyzing the social aspects of education, emphasized that "what we call social pedagogy is not some separate field of pedagogy that is opposed to the individual, it is only a concrete realization in the education of the principle that a child can only develop fully in socially organized cell "[15, p. 129]. Therefore, pedagogy, according to her, "should be put on the social ground, it educates for life, because it itself is a manifestation, a part of life" [15, p. 6].

This interpretation did not prevent a scientist one of the first in Ukrainian pedagogy to characterize such socio-pedagogical concepts as socialization of personality, social education, social environment, which modern science has identified as the leading categories of a new branch of pedagogical knowledge for Ukraine - social pedagogy. They are most fully outlined in her work, The New School of Social Education, which, according to S. Siropolka's definition, "gives the basic concepts of social education and introduces the means that lead to the development of the child's social instinct" [18, p. 277], in the scientific researches "Modern trends in new pedagogy", "Social education: its importance in public life" and in the article "Public issues of education".

In tracing the genesis of pedagogy as a social science, looking at "the main manifestations of new pedagogy", Sophia Rusova formulated the following general requirements for education: it must, firstly, be individualized, secondly, socialized, thirdly, industrialized, to cause the greatest creative activity in the student $[15$, p. 2]. At the same time, the "true apostle of individualism" in pedagogy was considered by J. J. Rousseau, the socialization of education - by J.G. Pestalozzi, who owes his assertion to this principle in pedagogy. It was put into practice by F. Frebel [15, p. 3].

The need to socialize the scientist derived from the social instinct of children, who at school age "becomes a controlling factor" in their upbringing and behavior, manifests in the desire for various forms of their "grouping", the need for friendship, personal sympathy, the desire to "achieve public praise" [15, p. 7-8]. According to her, "all harmony of human relations depends on socialization" [9, p. 49]. Seeking to give a "good direction" to socialization, S. Rusova identified her ways and means, in particular: "1) From the first year, to teach a child to strangers, to surround them with such relationships, so that she grows up with the feeling that people and the environment give only pleasant impressions, and they should be welcomed ... 3) At the earliest opportunity ... to establish a social environment for the child ... ... to ensure that the child is not miserable in the community, to treat the company with sincere grace, with equal respect. 4) ... as early as possible, to give the child the social responsibilities appropriate to his or her development and development: to serve breakfast, to clean the house, to help the younger companions to dress, to wash, etc. 5) ... to demand from the child a conscious actions to help someone else, but we learned that she is in need. 6) Not only individual works, but also collective ones should be organized, where everyone unites their creative thought, their shared impressions for the benefit of not the workers themselves, but to someone else - either a circle, or a collective, or a weak friend ..." [11, p. 60-61].

In S. Rusova's writings, such a new, relevant and for our present, social and pedagogical concept, as "socialization of the students' worldview", was found to be justified and substantiated. The educator understood it as "the development of public consciousness" [13, p. 65], which will help to develop the habit of "constantly being guided in their ranks not only by their own interests but also by those of their fellow citizens" [13, p. 5]. She regarded school self-government and collective activities as important grounds for socializing outlook, as well as "socializing" curricula, i.e. adapting them "and their content and volume to the nature of the child as she is and to her needs in the citizenship in which she lives" [13, p. 65]. At the same time, the scientist warned that the socialization of curricula should not be confused with "practicum, nor with professionalization", as it was in the Soviet school of the 1920 s - the beginning 1930s pp. 
Sofia Rusova called social education a strong factor for the education of the nation [13, p. 9]. In analyzing the essence of this term, not fully understood in either pedagogical theories or in the practice of education, she considered it from the standpoint of the proponent of individualization of education. She was first of all interested in the question: "how to bring these two new pedagogical trends - the individualization of education and its socialization - to agreement?" [13, p. 4]. According to the thinker, the first relies almost exclusively on the development of all the "mental forces" of the child, while the second acknowledges the huge impact on the child not only "heredity and individual nature, but also the social environment." As a result, for the purpose of individual upbringing, the teacher has identified the broad free development of all the spiritual powers and abilities of the child, which will enable her to "be of use to a small or large citizenship." Social education "tries to develop in the child those special traits that will further enable her to become the best citizen." Such a formulation of the purpose of individual and social education implies its conclusion: since "the citizens most need persons with well-developed abilities, we see that the purpose of education and social and individual one, but the ways to achieve it are not the same" [13, p. 4].

Guided by the statement that "the development of the child is influenced by three main factors: education, heritage, environment" [11, p. 27], based on the experiments of foreign (German, Belgian, Czech) scientists, the scientist revealed the specifics of social and educational influence of the environment. An indispensable condition for its effectiveness was the following: "the cell in which a child develops should not be too wide and consist of a very large number of diverse persons" [13, p. 37]. In addition, the educator identified the social groups ("social units") that most effectively influence the upbringing of children: the family ("but it does not require that the child is subjected to too much authority by the parents" [9, p. 166]); preschools (nurseries for babies, kindergartens, children's homes, playgrounds); a school "in which social needs and competitions must be balanced and from which neither people preserved in the traditions of the past, nor idealistic dreamers who are incapable of practical modern life should emerge" [13, p. 41]. The teacher considered play as the first "world" social form of association of children. According to her, it is play and work that "have always been and will be those natural processes in which social tendencies, feelings and social consciousness are best expressed and developed" [13, p. 38].

At the same time, I emphasize the shaft that no child "is passively influenced by the environment: it takes from it what its individuality seeks" [13, p. 36].

In the creative heritage of Sofia Rusova, there is an attempt to find out the problems of education and education of "defective" children, that is, to touch on important aspects of special education. In their decision it was guided by the provisions that children "of all ranges, children healthy and defective - all are necessarily subject to process education" [15, p. 1]. When she was asked "Who to educate and teach?" the school teacher should answer: "The school should accept all children," including "poorly understood," "underdeveloped," "defective," which are the result of "abnormal conditions in our lives." According to her, they should also receive "education possible to their strengths" [14, p. 162]. The "child offenders", for whom the school should be organized, should not be left out of the educational influence, should be surrounded by a teacher with a deep psychological understanding of sick students, with a heart warmed by love for them, and with a certain understanding of social and pedagogical task: to return these children to citizenship ... " [14, p. 162].

Psychological and pedagogical principles of work with children with intellectual disabilities Sofia Rusova considered in the article "About defective children at school". Acquaintance with the experiments on the "abnormal" children of foreign psychologists and educators of the time (G. Woodrow, A. Bine, V. Lai, G. Straper, L. Termen, etc.) led the scientist to conclude that it is "very important in in modern schools, there is a certain classification of children according to their intelligence "through testing, questioning, observation [6, p. 34]. However, an experienced humanist educator warned: "No matter how thoroughly we look at all the traits of defective students, it is very difficult to put the diagnosis and make it into the category of abnormal ones. An equally unhealthy child with a lack of observation should be sent to a special school or sanatorium - whether the patient is in vain to be detained in a regular school" [6, p. 78]. 
The article answers the questions about the causes of mental defects in children (inherited diseases of parents, their unhealthy lifestyle; illnesses transmitted by mother during pregnancy; incest in the family; social conditions), reveals the evolution of citizenship views on this category of people and the history of formation public institutions for children with mental disabilities in England, Denmark, Germany, USA, Switzerland. The scientist was impressed by the tasks and principles of the activities of the first schools and shelters of this type: "to give ... the greatest possible development to all ... drowsy abilities and to return ... the energized forces to useful activity under the control of disciplined will"; to awaken the mental powers of children to "some useful work ..." [6, p. 83]. The author's own conclusions concerning the peculiarities and methods of teaching and educating anomalous children, the almost extensive program of pedagogical activity contains the last (seventh) subdivision of this work, the main provisions of which can be summarized as follows: methods and programs of ordinary schools are not suitable "for the backward and low-minded students"; there should be separate schools or classes for this category, "where all their sleepy mental powers and inclinations would be easily and imperceptibly invoked" [6, p. 85]. The course of study here should be simplified; great attention should be paid to physical labor, motor development of children. In such schools, one general curriculum and curriculum is undesirable; the number of children in the class should not exceed 12. Much attention should be paid to the health care under the supervision of a doctor and others. S. Rusova considered the fact that "defective" children "should not live in isolation" as an indispensable condition of educational upbringing [6, p. 86]. The analyzed article also contains practical annexes: A. Binet-Simon tests, L.Termen's questionnaire for parents, psychographic schemes for the study of children, samples of exercises, etc. Therefore, the list of industries in which S. Rusova's scientific talent has appeared should include pedagogy of children with developmental disabilities, especially mental.

\section{CONCLUSIONS}

Summarizing the mentioned above, it can be argued that the issues of inclusion, education, education of children and young people with special educational needs, as represented by the property of Sofia Rusova in the period of migration, are a significant contribution to Ukrainian and world pedagogical thought, an important factor in the revival of national educational systems on the best examples of teaching and educational experiences of the past.

\section{REFERENCES}

[1] Doroshenko N. Sofia Rusova, as a teacher. The path of education and training, 1 (1936), 4-10. (in Ukrainian)

[2] "About Education": Law of Ukraine. Available at: https://zakon.rada.gov.ua/laws/show/2145-19/stru

[3] Rusova S.F. Selected pedagogical works. Osvita, Kyiv, 1996. (in Ukrainian)

[4] Rusova S. The Education and Sociology of Durkheim. Suspilstvo, 3-4 (1926), 139-142. (in Ukrainian)

[5] Rusova S. Some of the philosophy of education. Vilna ukrayinska shkola, 10 (1918). (in Ukrainian)

[6] Rusova S. Something about defective children at school. The path of education and training, 1 (1935), 3441. (in Ukrainian)

[7] Rusova S. Didactics: Synopsis of lectures delivered in M. Drahomanov Ukr. Teaching Institute in 1924/25. Siyach, Prague, 1925. (in Ukrainian)

[8] Rusova S. The soul of the young man and his upbringing. In: Woman, 3. Lviv, 1937. (in Ukrainian)

[9] Rusova S. The importance of social psychology for education. The path of education and training, 1-5 (1931). (in Ukrainian)

[10] Rusova S. Once upon a time. In: The 25th Anniversary of the Ukrainian Funeral Home. Lviv, 1927. (in Ukrainian) 
[11] Rusova S. The New School of Social Education. Ukrainian publishing house in Ekaterynoslav, Katerynoslav-Leipzig, 1924. (in Ukrainian)

[12] Rusova S. Idealist educator Adolf Ferrisr. The path of education and training, 7 (1931). (in Ukrainian)

[13] Rusova S. Social Education: Its importance in public life. The path of education and training, 1-3 (1930). (in Ukrainian)

[14] Rusova S. Public education issues. Life and Knowledge, 6 (1929). (in Ukrainian)

[15] Rusova S. Modern trends in new pedagogy. The path of education and training, 1-4 (1932). (in Ukrainian)

[16] Rusova S. Theory and Practice of Preschool Education. Ukrainian public publishing house, Praga, 1924. (in Ukrainian)

[17] Syniov V., Shevtsov A. A New Strategy for the Development of Correctional Pedagogy in Ukraine. Defectology, 2 (2004), 6-11. (in Ukrainian)

[18] Syropolko S. S. Rusova New School of Social Education. Teacher, 7 (1924). (in Ukrainian)

[19] Nagachevskaya Z.I. (Ed.) Sofia Rusova and Halychyna: Collection of articles and materials. Vik, IvanoFrankivsk, 1996. (in Ukrainian)

[20] Dzhus O., Nagachevska Z. Sofia Rusova: From the less known and the unknown. Part 1. "Nestorka Ukrainian Pedagogical Literature ..." Gostinets, Ivano-Frankivsk, 2006. (in Ukrainian)

[21] Central State Archives of Higher Authorities and Administration of Ukraine. Fond 3889, op. 2, case 24. (in Ukrainian)

Address: Oksana Dzhus, Vasyl Stefanyk Precarpathian National University, 57, Shevchenko Str., IvanoFrankivsk, 76018, Ukraine.

E-mail: dzhus1.oksana@gmail.com

Received: 15.01.2020; revised: 04.03.2020.

Джус Оксана. Питання інкдюзії та спеціальної педагогіки у творчій спадщині Софії Русової. Журнал Прикарпатського університету імені Василя Стефаника, 7 (1) (2020), 71-80.

У статті проаналізовано питання інклюзії та спеціальної освіти у творчій спадщині Софії Русової - педагога, громадянки, політика, державотворця, яка розглядала їх у контексті світових наукових здобутків міжвоєнної доби $\mathrm{XX}$ ст. Не використовуючи ці терміни, вона тлумачила інклюзію як процес збільшення ступеня участі всіх громадян у суспільстві, зокрема й тих, які мають фізичні чи ментальні порушення, передбачала розробку і застосування таких конкретних рішень, які зможуть дозводити кожній дюдині рівноправно брати участь в академічному і суспідьному житті. Еволюцію ідеї інклюзії та зародження спеціальної освіти С. Русова тісно пов'язувала з розумінням і тлумаченням провідних засад педагогіки, загальної та соціальної психології, соціології, філософії освіти, історичко-педагогічних пошуків кінця XIX - початку XX ст.

Чи не найваждивішим джерелом нових педагогічних ідей С. Русової, які втілилися у працях міжвоєнного періоду ("Нова школа соціяльного виховання", "Виховання і соціологія Дюркгейма", “Соціяльне виховання: Його значіння в громадському житті", “Суспільні питання виховання"), стало знайомство з новітніми течіями у західноєвропейській педагогіці, що дозводило їй іти в ногу з часом, психодогізувати педагогіку. Широка освіта, вільне володіння провідними європейськими мовами (уможливили доступ С. Русової до оригінальної літератури - праць Дж.Дьюї, Е. Клапареда, Г. Кершенштейнера, В. Лая, Е. Меймана, Г. Спенсера, забезпечили безпосередне спілкування 3 найвидатнішими педагогічними діячами 1920-х1930-х рр., зокрема О. Декролі й М. Монтессорі, та вивчення досвіду їх практичної роботи. Керуючись положенням про те, що “розвиток дитини проходить під впливом трьох головних факторів: виховання, спадщина, оточення", базуючись на дослідах зарубіжних (німецьких, бельгійських, чеських) учених, вчена розкрила специфіку соціальновиховуючого впливу середовища, готуючи підгрунтя для розкриття сутності інклюзії як сукупності 
умов, способів і засобів їх реалізації для спільного навчання, виховання та розвитку здобувачів освіти з урахуванням їхніх потреб та можливостей. Водночас вона підкреслю вала, що жодна дитина "не піддається пасивно впливу оточення: вона бере з нього те, до чого прагне ії індивідуальність". Питання власне спеціальної освіти, зокрема психодого-педагогічні засади роботи 3 дітьми із вадами в розумовому розвитку, найбільш повно розкрито у праці С. Русової “Дещо про дефективних дітей у школі". У ній чітко простежується ідея про те, що діти всіх верств обов'язково підлягають процесові виховання і навчання. На думку С. Русової Не можуть залишитися поза виховним впливом і діти 3 девіантною поведінкою (зокрема, “діти-здочинники”), для яких у місцях відбування покарання повинні бути створені умови для набуття освіти як чинника їх перевиховання, а для потреб таких шкіл доцільно організувати підготовку учителів “з гдибоким психологічним розумінням своїх хворих учнів, з серцем, огрітим любов'ю до них, і з певним розумінням свого суспільно-педагогічного завдання: вернути цих дітей громадянству...". Отже, питання інклюзї̈, навчання, освіти дітей і мододі 3 особливими освітніми потребами, репрезентоване надбаннями Софії Русової, є вагомим внеском в українську і світову педагогічну думку, важливим чинником відродження національної системи освіти на кращих зразках навчально-виховного досвіду минулого.

Кдючові слова: інклюзія, спеціальна освіта, соціалізація, особистість, дитина, професійна (фахова) підготовка, творча спадщина, Софія Русова. 